\title{
A hibridização de gêneros jornalísticos como estratégia dialógica: uma análise do Conversa de Redação, do Jornal da Itatiaia
}

\author{
MOZAhir SALOMÃo BRUCK \\ Pontifícia Universidade Católica de Minas Gerais - mozahir@uol.com.br \\ Jornalista, professor de Jornalismo e pesquisador do Programa \\ de Pós-Graduação em Comunicação Social da PUC Minas. \\ Katia Teotônio de Castro \\ PUC Minas Gerais - castro.katia@uol.com.br \\ Mestranda em Comunicação Social da PUC Minas.
}

\begin{abstract}
Resumo
Este artigo se propõe a discutir, a partir do quadro Conversa de Redação, do Jornal da Itatiaia, transmitido diariamente pela Rádio Itatiaia de Belo Horizonte, alguns movimentos de estilo e de hibridização de gêneros que, mais recentemente, parecem ganhar ênfase no radiojornalismo brasileiro: a saber, a adoção de posturas e estratégias discursivas, pelos jornalistas de sobrepor informação, comentário e opinião em suas narrativas, na busca de estabelecer uma inscrição narrativa de natureza mais dialógica e pretensamente mais esclarecedora.
\end{abstract}

Palavras-chave

Rádio, gêneros jornalísticos, dialogismo, contrato de leitura.

\begin{abstract}
This article proposes to discuss some styles and genre hybridization movements based on the programme Conversa de Redação, which is daily broadcasted on Rádio Itatiaia, in Belo Horizonte. More recently, these movements seem to be gaining emphasis on the Brazilian radio journalism, namely: the adoption of discursive posture and strategies by the journalists of overlapping information, comment and opinion in their narratives in order to establish a narrative inscription of a more dialogic nature and supposedly more enlightening.
\end{abstract}

Keywords

Rádio, journalistic genres, dialogism, reading contract.

Artigo recebido em 14/09/2011

Aprovado em 29/02/2012 
ma das alegorias recorrentemente utilizadas sobre a mídia radiofônica e o modo como esta se faz presente na sociedade é do rádio como extensão da praça pública. Em função de suas sabidas e inerentes características como o imediatismo e dialogicidade, o rádio oportuniza à cidade - no caso, aos ouvintes - não apenas tomar conhecimento das informações e acontecimentos, mas de compartilhar, a partir das experiências e possibilidades de cada receptor, das opiniões e comentários feitos por esses jornalistas e comunicadores que atuam na emissora.

Como se dirá à frente, o rádio estabelece com os ouvintes dinâmicos e difusos (BRAGA, 2009) contratos de leitura que, cotidianamente, parametrizam a programação oferecida ao público. Valendo-se desses contratos, o rádio acaba por estabelecer conexões intensas com seu público em termos dos modos como se faz presente na vida do receptor. Institui-se, como alguns autores já denominaram, como um envelope sonoro da realidade. Uma experiência diversa e esteticizada do cotidiano.

A noção de dialogismo de Mikhail Bakhtin pode nos ajudar a melhor compreender essa característica de dialogicidade, tão inerente ao rádio. Para o autor, a linguagem constitui-se no permanente diálogo entre os vários dizeres no espaço histórico-social e o fundamento da interdiscursividade, da troca incessante entre os discursos, adquire, portanto, uma dimensão diversa, que engloba desde um plano de alteridade mais restrito, da comunicação interpessoal, até o movimento de circulação dos dizeres numa esfera extremamente ampla, como a da própria dinâmica da vida e da cultura. Ao estabelecer o dialogismo como um princípio epistemológico, Bakhtin passa a entendê-lo, então, a partir de algumas perspectivas, a saber: i) seja, de modo pontual, um diálogo como relação entre falantes numa situação específica de comunicação, em que ocorre alternância de papéis e turnos de fala; ii) como diálogo como articulação entre um discurso e os demais que o atravessam e constituem; iii) diálogo entre discursos que configuram uma cultura, uma sociedade e, por último, iv) diálogo que marca a natureza interdiscursiva constitutiva da linguagem. Neste estudo, especialmente, nos interessam os três últimos pontos.

Mikhail Bakhtin entende que toda e qualquer produção de sentido é resultado de um intenso e permanente diálogo, um entrecruzamento entre as perspectivas acima que 
envolvem as diferentes formas de compreensão do mundo em que estamos inseridos. Os sentidos, assim, não estariam 'localizados' em nenhum lugar ou ponto específico, mas estariam em constante e frenética circulação nas diferentes dimensões e circunstâncias da vida humana.

Outra noção bakhtiniana importante nesta reflexão parece ser o que o autor denominou de 'lei de posicionamento'. Nossa relação com o mundo se dá a partir de um ponto de vista, já que não é possível ocupar, ao mesmo tempo, todos os espaços que o envolvem. Tem-se, então, esse excedente de visão, que está além do que se vê, mas é justamente o que o 'outro' vê. Daí a necessidade do diálogo com o 'outro', de ter acesso à sua 'resposta', ao ponto de vista segundo, no sentido de apreender o objeto e imprimir uma significação possível para ele, considerando-se que há diferentes focalizações de um mesmo fenômeno. Os diferentes posicionamentos presentes na construção das compreensões e valorações dos fatos também são decorrentes dos contextos social, histórico e cultural. E, ao acionarem a engrenagem da linguagem na produção dos atos enunciativos, tornam-se constitutivos desse ato. "A vida é dialógica por natureza", sintetiza Bakhtin, tentando demonstrar que é impossível pensar no homem fora das relações que o ligam ao outro.

\section{Os contratos de leitura no jornalismo radiofônico}

Ao estabelecer uma comparação entre os contratos de leitura e modos narrativos das rádios Itatiaia e $\mathrm{CBN}$, no livro Jornalismo Radiofônico e vinculação social, BRUCK (2003) destaca que o contrato de leitura pode ser entendido como um acordo afetivo-intelectivo que os media e os públicos estabelecem entre si. Os contratos revelam mais do que a opção do receptor pelo modo de esses media mostrarem o mundo, "denotam definições a partir de identificações e representações que se estabelecem a partir do político e do ideológico, ética e da moral, do estético e do psicológico.” (BRUCK, 2003, p.45).

Os contratos se estabelecem a partir de condições e determinantes para a leitura de um veículo, funcionando como reguladores das relações midiáticas. Por isso mesmo, aspectos como a credibilidade que o veículo constrói na linha do tempo, as concessões 
diante das exigências e demandas do público e as estratégias por meio das quais este institui e operacionaliza sua identidade estética são definidores desses contratos.

VERÓN (1983) define o contrato de leitura como a relação entre o suporte e sua leitura ou, ainda, como os media procuram construir um vínculo ativo com o receptor. $\mathrm{O}$ autor chama a atenção para o fato de que o sucesso de um veículo pode ser medido pela sua capacidade de: i) propor um contrato que se articule corretamente às expectativas, motivações, interesses e aos conteúdos de imaginário do alvo visado; ii) fazer evoluir o contrato de leitura de modo a 'seguir' a evolução sociocultural dos leitores e iii) de modificar seu contrato se a situação concorrencial o exigir, fazendo isso de uma maneira coerente.

O rádio, em função das especificidades já mencionadas neste artigo, estabelece paradoxalmente tipos específicos e muito abertos de contratos de leitura. No rádio, as operações enunciativas propostas pelo enunciador e as ofertas de lugar feitas ao destinatário são de uma enorme e instigante multiplicidade e que buscam se ratificar e renovar a cada momento. São reforçados ao longo da programação em que produtores, locutores e jornalistas se ocupam em construir uma programação marcada por visões peculiares de mundo e, em geral, definidas pelas projeções que estes fazem sobre a recepção.

Importante ressaltar que para a programação noticiosa a noção de contratação de leitura também modaliza e influencia o 'fazer' jornalístico das emissoras radiofônicas. Pode-se afirmar que entre o ouvinte e a cobertura jornalística pela qual este opta (a emissora de sua preferência), de início, dois compromissos já se estabelecem: o de reconhecimento e o de adesão. Ao mesmo tempo em que, como critério de escolha de audiência, o ouvinte busca se identificar com os atos de fala e modos e formas de abordagens das coisas do mundo, o ouvinte sedimenta sua relação ativando processos de afetividade e aproximação com a programação eleita. Daí, portanto, as amplamente distintas propostas em termos de critérios de noticiabilidade, modos de abordagem e soluções de plasticidade apresentadas pelas emissoras para a apresentação das notícias e das informações de interesse da audiência. 


\section{Notícia e informação}

Não é incorreto afirmar que os protocolos, perspectivas e modos pelos quais o rádio aborda a notícia devem ser percebidos a partir de características que lhe são específicas, em especial, a sua natureza acústica - leia-se também oralizada. Os próprios critérios de noticiabilidade no jornalismo radiofônico se mostram muito mais "generosos" do que em outras mídias, por exemplo, como a televisão. Como a expressão fundamental se dá por meio da oralização do conteúdo - ou seja, a palavra falada - além da narração do próprio fato, a notícia radiofônica se institui encampando, sem dificuldades, e mesmo que exclusivamente, perspectivas, riscos, ameaças, avaliações, repercussões etc. As ameaças, por exemplo, de uma categoria de servidores públicos, mesmo que das áreas da saúde ou educação, de entrar em greve, não seriam facilmente incluídas como notícia em um telejornal, mas no rádio, onde imperam as trocas e embates discursivos baseados na palavra sonorizada e que, geralmente, tem um forte apelo popular e de serviço, tal pauta teria espaço garantido.

Mas se essas são diferenciações possíveis no cotejamento entre o jornalismo radiofônico e o praticado nas mídias impressa e televisiva, a tentativa de tentar compreender a relação do rádio com a informação já foi objeto de outras incursões. É bem conhecido o estudo de MEDITSCH (2001), que propôs uma distinção entre radiojornalismo e rádio informativo. Para o autor, o primeiro aspecto a ser superado é a exclusiva associação do rádio informativo à oralidade - assim como o jornalismo impresso é associado à escrita. Meditsch propõe a superação dessa antítese por uma síntese, pois "a linguagem do rádio vai além da oralidade e da escrita, absorve características de ambas para as negar.”(MEDITSCH, 2001,p. 148).

Meditsch nos lembra que a base material histórica a partir da qual o radiojornalismo se estabeleceu foi o jornal impresso. Por isso mesmo, o rádio fundamentou sua narrativa, prioritariamente, na palavra sonorizada. Mas Meditsch pondera, ao mesmo tempo, que, historicamente, mesmo tendo ainda permanecido, de certo modo, refém da lógica da escrita, o rádio estabeleceu mais do que uma linguagem própria, mas valeu-se de sua condição acústica para propiciar ao receptor uma nova e específica experiência de esteticização do cotidiano. Por isso mesmo, ao deter-se, 
especialmente, na tentativa de tentar melhor compreender as manifestações do rádio informativo contemporâneo, o autor explicita seu entendimento que o rádio atual alterou seus modos de perceber o mundo, registrá-lo e narrá-lo.

$\mathrm{O}$ rádio informativo fala de coisas que, anteriormente, não eram notícia (a hora certa, por exemplo), e revoluciona a ideia da reportagem com as transmissões ao vivo. Aprofunda e contrapõe ideias e opiniões com facilidade e orienta as massas urbanas como o cão de um cego. Põe em contato os mais remotos pontos do interior e concede espaço para o receptor se manifestar como nenhum outro meio. É um serviço quase sempre gratuito, que não toma tempo nem monopoliza a atenção do público. E é assim: mesmo sem a palavra escrita e sem as imagens, suportes que, para muitos, parecem esgotar todo o mundo da informação de nosso tempo. Por isso, requer uma nova conceitualização que dê conta de sua amplitude e especificidade. (MEDITSCH, 2001, p. 31).

Para este estudo, interessa-nos, especialmente, compreender além dessas alterações apontadas por Meditsch como que, em função e no contexto, certamente, de novas posturas e comportamentos que vimos experimentando com as novas mídias e redes sociais, o radiojornalismo e o rádio informativo, relevando o conceito proposto pelo autor, parece também proceder a alterações no modo como articula, no âmbito do noticiário, a informação, a interpretação e a opinião. A presença desses gêneros não é uma novidade em si no universo radiofônico, mas, como se verá à frente, a adoção, mais recentemente, de espaços assumidamente opinativos, com angulações e enquadramentos assumidos pelos próprios repórteres - colocando em questão a tradição do afastamento e isenção tidos como característica do jornalismo em países como o Brasil - merece, certamente, uma reflexão mais detida.

\section{Os gêneros jornalísticos no rádio}

Há, certamente, nos estudos acerca dos gêneros presentes no jornalismo uma ampla diversidade em termos das compreensões a respeito dos mesmos e do modo como podem ser sistematizados. Na verdade, a discussão sobre gêneros apresenta controvérsias em si mesma - seja pelo fato de que para alguns estudiosos que percebem neles uma fragilidade conceitual em função das complexidades inerentes à própria linguagem e às discursividades, seja pelo fato de que esses gêneros não dariam conta, 
em suas tipificações e rotulações, de uma efetiva cobertura nocional que abrangesse todo o conjunto de textos presentes no campo jornalístico.

Ao mesmo tempo em que se fala em gênero informativo, este, na verdade, refere-se a uma das categorias do jornalismo. As outras categorias seriam o interpretativo e o opinativo. Há, portanto, uma sobreposição terminológica em que, não raramente, se confunde gênero, categoria e formato. Autores como MELO (1985), REZENDE (2000) e BARBOSA (2003), por exemplo, mencionam os gêneros notícia, nota, reportagem, comentário e artigo.

José Marques de Melo retomou na década de 1980 o estudo dos gêneros presentes no jornalismo brasileiro. Marques de Melo (1994) retomou, à época, particularmente, as proposições de Luiz Beltrão sobre as categorias informativo, interpretativo e opinativo. Marques de Melo ratificava o entendimento de Luiz Beltrão sobre os gêneros informativo, interpretativo e opinativo, mas afirmava existirem incongruências em relação ao gênero interpretativo. Mais recentemente, em entrevista à pesquisadora Lia Seixas ${ }^{i}$, Marques de Melo disse que o que afirmara anteriormente havia sido interpretado equivocadamente, pois ele não defendeu que existissem apenas dois gêneros (informativo e opinativo), mas que à época de sua pesquisa, os gêneros que pôde observar em sua pesquisa, na imprensa brasileira, foram apenas esses dois. Atualmente, em seu trabalho de acompanhamento da imprensa, Marques de Melo afirma que tem observado a coexistência de cinco gêneros: informativo, opinativo, interpretativo, utilitário e diversional.

Para este trabalho, optamos por pensar os gêneros a partir da perspectiva da intencionalidade e dos modos de leitura do real - vertentes que Marques de Melo (1985) percebeu distintamente. Valemo-nos, por isso, dessa noção mais fundamental acerca dos gêneros jornalísticos, descrita por Luiz Beltrão na década de 1970, quando o autor defendeu, como já se afirmou, a prevalência dos gêneros informativo, interpretativo e opinativo.

Entendemos ser essa a aplicação mais adequada para este artigo, já que em nosso objeto de análise ( o quadro Conversa de Redação, do Jornal da Itatiaia), os enunciados apresentam perceptíveis traços de descrição e narração, de reflexão e problematização 
dos assuntos abordados e de opinião a respeito desses. Em geral, as opiniões são apontadas por meio de comentários com maior ou menor carga de adjetivação. $\mathrm{O}$ comentário, também herdado do jornalismo norte-americano, teria surgido da evolução do jornalismo a partir do rádio e da televisão. A agilidade desses veículos cria no cidadão a necessidade de saber mais sobre os acontecimentos. Marques de Melo (1985) identifica o comentário como um gênero intermediário entre o editorial e a crônica, porque utiliza o método expositivo do editorial, mas introduz a ironia e o humor da crônica.

Em seu clássico A opinião e a multidão, Gabriel Tarde (1991) afirma que a opinião está para o público como a alma está para o corpo. Nesse estudo sobre como a opinião pública, historicamente, se funda e se dissemina, o autor destaca que ao jornalismo coube a tarefa de, depois do desenvolvimento dos correios, dos meios de transporte e das ligações por estradas entre as localidades, contribuir para a construção do espírito público e a noção de nação. Com a imprensa, o mundo fícou menos desconhecido e limitado.

TARDE (1991) entende que a própria veiculação da informação é, por si, um fator de constituição da opinião. Não se interessou o autor em refletir sobre aspectos como a objetividade e a imparcialidade das notícias, qualidades autoproclamadas por uma parcela expressiva dos media noticiosos. Até por que esses são estudos desenvolvidos pelo autor no final do século XIX ${ }^{\text {ii }}$ e início dos anos 1900. Mesmo assim, Tarde já percebia o poder da imprensa e seu potencial impacto na constituição da opinião pública.

O jornalismo é uma bomba de aspiração de informações que, recebidas de todos os pontos do globo, cada manhã, são propagadas no mesmo dia por todos esses pontos do globo nos aspectos que são ou parecem ser ao jornalista mais interessantes, ao serviço dos seus objetivos e do partido que eles formam. As informações dos jornalistas são, realmente, impulsos irresistíveis. Os jornais começaram a exprimir opinião, primeiro a opinião exclusivamente local dos grupos privilegiados ( a corte, o parlamento, a capital), reproduzindo as desavenças caseiras, as discussões e os discursos, e acabaram por dirigir a opinião quase a seu bel-prazer e por modelá-la, impondo a maior parte dos assuntos quotidianos como temas dos discursos e das conversas.(TARDE, 1991,p.67) 
Gabriel Tarde salienta, no entanto, que aquilo que a imprensa divulga só terá força se os leitores, entre si, repercutirem o que leem. Daí, a importância que o pensador francês dá ao estudo sobre como o cidadão traz para o seu dia a dia os assuntos de natureza pública que acessa das mais diferentes maneiras. Nesse sentido, TARDE contribui ainda mais com esta reflexão ao desenvolver uma noção muito instigante a respeito da conversa, que o autor entende ser o "fator de opinião mais contínuo e universal” (TARDE, 1991, p. 72). Apesar de também perceber a conversa como "qualquer diálogo sem utilidade direta e imediata, onde se fala por falar, por prazer, brincadeira ou cortesia" (TARDE, 1991, p.73), o autor vê nela o agente mais poderoso da propagação dos sentimentos, das ideias e dos modos de ação.

Tomando as perspectivas de Tarde sobre opinião - e a imprensa e a conversa como seus fatores de propagação - é que nos dispomos a analisar o quadro Conversa de Redação, do Jornal da Itatiaia. A partir de Tarde, nosso entendimento é de que o mencionado quadro se vale, mesmo que artificialmente, do estatuto da conversa para, por isso e assim, articular condições que lhe garantam uma licenciosidade para operar, de forma hibridizante e hibridizadora, opiniões, interpretações, novas informações, chistes e silêncios - também esses carregados de muito sentido. Ou como destacou o autor:

Nunca observamos ninguém com toda a nossa capacidade de atenção a não ser quando falamos (ou nos batemos em duelo) com esse alguém. É esse o efeito mais constante e o mais importante de uma conversa, ainda que seja o menos notado de todos. É a conversa que marca o apogeu da atenção espontânea que os homens se dispensam mutuamente e através da qual se entrepenetram com maior profundidade que noutra qualquer relação social. (TARDE, 1991,p. 73)

\section{O jornalismo da Rádio Itatiaia}

A Rádio Itatiaia, fundada em 1952, transmite uma programação apoiada no tripé jornalismo, esporte, prestação de serviço e música. É transmitida pelas frequências 610 $\mathrm{kHz}-\mathrm{AM}$ e 95,7 MHz - FM, e está entre as cinco mais importantes do Brasil. $A$ "rádio de Minas", como a emissora se autodenomina, chega a quase 90 por cento dos municípios mineiros e é líder geral no IBOPE com 115.073 ouvintes por minuto. É 
também disparada líder em alcance: 1.824 .258 pessoas diferentes ouviram a emissora em março de 2011.

A aposta da rádio Itatiaia no jornalismo e na programação esportivo se deu já no momento de fundação da emissora. No ano de fundação da Itatiaia, Belo Horizonte contava com três emissoras: Inconfidência, Guarani e Rádio Mineira, que apresentavam uma programação prevalecente à época: o radioteatro, programas de auditório e programas de curiosidades. A nova emissora apresentou, então, seu diferencial: espaço para esporte e notícias. Ainda em 1952, a Itatiaia cobriu os jogos das Olimpíadas Universitárias e, em 1954, por quase dois dias ininterruptos, o julgamento de um crime que envolvia a alta sociedade de Belo Horizonte. A partir da cobertura destes dois eventos ficava claro o projeto de jornalismo desenhado pela emissora.

A Rádio Itatiaia possui um jornalismo reconhecido, em termos de sua audiência e pela credibilidade junto ao público, em função de seus noticiários que estão no ar há quase cinco décadas. Destaque para o Jornal da Itatiaia que, atualmente, vai ao ar todos os dias em duas edições: a primeira, de $06 \mathrm{~h} 30$ às $09 \mathrm{~h}$, e a segunda, de $12 \mathrm{~h} 30$ às $13 \mathrm{~h}$. Se o Jornal se estrutura ainda sobre o tradicional modelo, com divisão esquemática que lembra as editorias (cidade, nacional, política, economia etc), fica explícita a priorização por parte dos editores, das notícias de interesse mais próximo ao cotidiano do ouvinte. BRUCK (2003) destaca que tal opção parece ser imprescindível para a emissora essa conexão entre a notícia veiculada e a vida concreta do ouvinte.

\section{O Conversa de Redação}

Desde o ano de 2005, a Rádio Itatiaia de Belo Horizonte tem encerrado o Jornal da Itatiaia - Primeira Edição, com o Conversa de Redação. Nesse quadro, que tem duração média de 10 minutos, alguns repórteres da emissora - e que, geralmente, acabaram de ter matérias e/ou reportagens elaboradas por eles exibidas naquela edição do dia do jornal - voltam a abordar alguns dos assuntos/acontecimentos já tratados, só que agora fazendo comentários e apresentando outros detalhes em relação aos mesmos.

Podendo ser entendido como um quadro de encerramento do jornal, o Conversa de Redação parece ter a proposta de estabelecer um momento em que o repórter, fora 
agora de sua engessada inscrição dentro do formato notícia, pode transcender a exclusiva narração do fato na sua emergência aparente e oferecer ao ouvinte contextos e explicações acerca dos acontecimentos abordados. Mais que contextos, no entanto, os jornalistas que participam do Conversa de Redação não se eximem de externar suas opiniões, construindo um discurso jornalístico alterado, em que se mesclam traços de informação, interpretação e opinião. Aos domingos, em vez do Conversa de Redação, o jornal é encerrado com outro quadro, o Observatório Feminino, em que as jornalistas da emissora tratam de temas e assuntos marcados pela questão de gênero e de maior interesse, a princípio, para mulheres.

Para a produção deste artigo, foram observadas três semanas - ao todo, vinte e uma edições - do Conversa de Redação. Os períodos observados foram os seguintes: 27 de setembro a 03 de outubro de 2010; 14 a 21 de fevereiro de 2011 e de 04 a 10 de julho de 2011. Observe-se que nas edições de domingo, o Jornal da Itatiaia em vez do Conversa de Redação leva ao ar o Observatório Feminino, apresentado por algumas das jornalistas que atuam na emissora. Os períodos foram assim definidos para, exatamente, garantir uma distribuição temporal do acompanhamento em momentos distintos dentro do período de um ano.

Entre os objetivos iniciais dessa observação, optamos por destacar:

- Se e em que circunstâncias os jornalistas que participam do Conversa de Redação traçam a distinção das ações de informação/interpretação/opinião;

- Eventuais registros de que no Conversa os jornalistas aprofundam na abordagem das notícias ou lhes acrescentam informações novas;

- A tendência à sugestão e à formação de opinião;

- Níveis de criticismo em relação aos fatos e informações: uso da ironia, ataques diretos, agressividade etc.

Com a participação geralmente de três ou, no máximo, quatro jornalistas, o Conversa de Redação, nas três semanas observadas, apresentou algumas características que parecem constantes: $i$ ) a 'conversa' é conduzida sempre por um dos apresentadores 
do jornal (geralmente, o jornalista Eustáquio Ramos) que vai, durante o quadro, por meio de textos curtos, elencando os temas a serem discutidos pelos participantes; ii) os jornalistas que mais participam do quadro, além de Eustáquio Ramos são os repórteres Eduardo Costa e Carlos Viana iii; iii) observou-se um efetivo estado de coloquialidade no modo como os jornalistas abordam os temas e se dirigem aos ouvintes e uns aos outros; iv) todos os participantes do quadro parecem não apenas tentar apresentar um 'contexto' dos temas em discussão, mas não se furtam em dar suas opiniões pessoais a respeito dos mesmos; e v) além de informativo, interpretativo e opinativo, o Conversa de Redação também faz aproximações com o entretenimento: os repórteres, muitas vezes, abordam o tema com tons de ironia ou humor.

A seguir, apresentamos algumas transcrições que entendemos que corroboram as observações acima. Para tanto, vamos identificar os jornalistas da Rádio Itatiaia com as seguintes iniciais : Carlos Viana (CV), Eduardo Costa (EC) e Eustáquio Ramos (ER). Em termos de sua plasticidade acústica, o quadro é aberto com uma vinheta específica em que, em meio a um som eletrônico e vozes ao fundo, sugerindo pessoas conversando, uma voz se destaca e anuncia o nome "Conversa de Redação".

Sobre o item iii, uma passagem bem ilustrativa da intensa coloquialidade presente no Conversa pode ser observado na edição do dia 04 de julho, uma segundafeira, quando os jornalistas discutiram sobre a precariedade dos telefones públicos (orelhões), como transcrito abaixo:

ER: Os orelhões estão pedindo socorro!!!

CV: Eu fiz a matéria atendendo pedido dos moradores e do administrador da própria empresa. De fato, dos 80 telefones, 30 estão estragados, inclusive os da própria empresa operadora. A resposta do diretor da Anatel ${ }^{\text {iv }}$ me soou assim: ah, pelo amor de Deus, para de me encher o saco (grifo nosso)... Essa foi a impressão que eu tive, com todo respeito com ele e com todo o respeito com o cargo que ele ocupa. Na verdade, é um direito básico.

ER: Tem uma determinação depois da privatização do serviço de telefonia, em 98. Foi determinado que às empresas e a Oi, aqui em Minas Gerais, que se instalasse um telefone público a cada 300 metros...

EC: Quem decide sobre transporte público em Belo Horizonte nunca andou de ônibus. Falá um negócio pro cê (grifo nosso): dez anos atrás, quando eu denunciei pela primeira vez, a Telemar fingiu de égua (grifo nosso). De lá pra cá, a própria Oi fica cabisbaixa porque houve o compromisso de colocar telefone público até na floresta, e eles colocaram. Quando a telefonia celular explodiu e a fixa passou a dar menos lucro, ignoraram. Vou repetir uma frase dita pela amiga de uma senhora 
que ia aos barzinhos para dar uns beijim: liga não boba: homem em Belo Horizonte é igual a telefone público - metade tá ocupada, a outra metade estragada. (grifo nosso).

Além da transcrição acima, nos programas observados, há uma constante presença de jargões, frases de efeito lúdico e ditados populares, que ratificam esses atos de fala, que inscrevem a narrativa em um plano essencialmente coloquial. Abaixo algumas frases colhidas nos programas:

“Tem duas coisas gravíssimas nisso, além da confusão na cabeça do eleitor, o que é uma sacanagem (palavra muito forte para usar tão cedo). Tem o Supremo com processos importantes parados e ficam discutindo esse chove não molha". (01 de outubro de 2010);

"Galinha choca 21 dias, cuida, a primeira coisa que faz é buscar alimento para os pintinhos. Tem muita mãe galinha melhor que mãe..." (27 de outubro de 2010)

"Como seria bom se cada um pagasse a sua conta pra gente não passar raiva com uns mão de vaca.”...(15 de fevereiro de 2011);

"Essa questão de radares... licitação... a gente sempre fica com o pé atrás.." de fevereiro de 2011)

Já o item $i v$ sintetiza, pode-se afirmar assim, o que é o Conversa de Redação. Todos os participantes parecem, em termos de como acordar uma ampla 'liberdade' para apresentar suas abordagens e opiniões a respeito dos temas escolhidos, mas sempre pensando-os à luz das leis estabelecidas e dos direitos e deveres do Estado e dos cidadãos. Nas transcrições abaixo, essa perspectiva fica evidenciada. Um ponto que causou polêmica entre os participantes foi ao ar no dia 07 de julho de 2011: a proposta da Prefeitura de Belo Horizonte de desligar os radares de avanço de sinal na cidade durante a madrugada. A justificativa é de que, ao parar o carro em alguns semáforos durante a madrugada, o motorista da capital mineira fica muito exposto ao risco de assaltos. A seguir, a transcrição de como o assunto foi abordado:

ER: Suspensão de multas para quem ultrapassar o sinal vermelho nas madrugadas. CV: É a melhor saída. No Brasil não há uma legislação única para o assunto. O que eu me lembro bem é que durante a administração Pimentel tinha essa orientação de que durante a noite as multas não seriam cobradas dos motoristas. A Bhtrans mudou a regra sem avisar.

EC: Ao agir assim o prefeito está demonstrando bom senso mas me desagradando profundamente. Como? Ele aplaca a polêmica e reconhece o risco do motorista mas porque me desagrada? Por que eu tenho insistido que nós só vamos melhorar o ambiente em que vivemos quando tivermos tolerância zero, e tolerância zero 
implica em ter sim a proibição de avançar sinal de noite. Mas então eu vou ser assaltado, Eduardo? (aqui o repórter faz a pergunta a si mesmo, como se falasse pelo ouvinte). Ora, vamos brigar para mudar o país, nosso jeito de ser...Nós estamos caminhando para um tempo que vamos ser obrigados a ficar dentro de casa e a pagar pelo ar que respiramos dentro de casa.

Outra característica sempre presente no Conversa de Redação é modo com que muitas vezes os jornalistas abordam determinados temas, aproximando-se do humor, mas também do chiste e do deboche. Nos trechos apontados a seguir, os repórteres com o objetivo ou de radicalizar em sua opinião ou mesmo para, ludicamente, apenas fazer um gracejo, optam por criar uma situação de 'humor' dentro do quadro:

Sobre o não resgate dos carros apreendidos e que ficam anos no pátio do Detran pois acumulam débitos maiores que os valores dos próprios veículos:

$\mathrm{CV}$ : Tem carro chique mas também tem muita porcaria. Outro dia mesmo vi um carro muito velho, amassado, acho que nem andava mais e com um cartaz: vendese ou troca-se por menor valor. Só se for uma bicicleta...

ER: Pois ei vi um anúncio na internet o anúncio da venda de um fusquinha muito velho. No vidro de trás tinha um cartaz: "vendo essa carniça. 500 reais'. $(27 / 09 / 2010)$

Sobre a votação do novo valor do salário mínimo:

EC: Estou vendo todo mundo defendendo um salário mínimo maior, mas tem muita conversa atravessada. Os tucanos defendiam um salário de 100 dólares. Já está em 300. Um salário de 450 "merréis" não é muita coisa não, mas quem disse que ACM Júnior e essa turma toda tem moral? Quem disse que o Paulinho Pereira, com a história recente dele, vai exigir alguma coisa? Quem disse que o grosso dos deputados vai encarar a Dilma no início do governo? Tem quatro anos pela frente para os deputados fazer ponte, fazer promessa, construir a escola que não vai ter porta nem janela mas vai ser construída e ganhar eleição de novo daqui a quatro anos, ou seja... ( o repórter engrossa a voz e fala solene) assim caminha a humanidade. $(17 / 02 / 2011)$

Sobre a queda do Ministro dos Transportes, Alfredo Nascimento:

EC: Me permita um versinho modesto para encerrar o conversa de Redação de hoje: sabe o que eu desejo para a patota do Ministro que saiu: que todos vão pra ponte que caiu; (07/07/2011).

\section{Considerações finais}

Este artigo resultou da observação de um quadro do Jornal da Itatiaia, de Belo Horizonte em que jornalistas tentam transcender os limites narrativos da notícia e buscam contextualizar o referente - o acontecimento - por meio de opiniões e a oferta 
de informações suplementares ao ouvinte, usando como estratégia discursiva para tal uma postura pretensamente dialógica, em que os jornalistas envolvidos estabelecem, entre si, uma conversa e na qual também incluem, indiretamente, por meio de referências e citações, o ouvinte.

O Conversa de Redação mescla os gêneros informativo, interpretativo e opinativo e, assim, acaba por constituir uma narrativa híbrida e fortemente coloquial. $\mathrm{O}$ quadro parece contribuir, de forma efetiva, para intensificar os laços de aproximação entre os ouvintes e a emissora. Por isso mesmo, parecem ir ao encontro da proposta geral de contrato de leitura que a Rádio Itatiaia busca acordar com seu público.

Apesar de poder-se afirmar que os participantes do quadro possuem ampla liberdade na formulação e apresentação de suas opiniões e comentários, interessante observar que, em geral, jornalistas comungam da maioria dos posicionamentos apresentados. Uma explicação para essa ausência de embates e discordâncias entre os participantes, talvez, seja a de que suas opiniões e comentários tomam como ponto de partida, mesmo que a partir da experiência e entendimento de cada comentarista sobre o fato em questão, de parâmetros bem demarcados como o interesse público, a legalidade, a noção de justiça social, de ética e valores morais.

Por esses, entre outros motivos, percebemos no Conversa de Redação a adoção de estratégias de natureza dialógica e de reforço das cláusulas da contratação de leitura entre a emissora e seus ouvintes. O quadro - além do interesse jornalístico que o envolve - reúne as mais consagradas características da mídia radiofônica: dialogismo, instantaneidade, colagem ao cotidiano dos ouvintes e pontes de identificação entre o receptor e a emissora.

\section{Referências}

BAKHTIN, Mikhail. Estética da criação verbal. São Paulo:Martins Fontes, 1992

BARBOSA F. André. Gêneros radiofônicos. São Paulo: Paulinas, 2003.

BRAGA, José L. Mediatização como processo interacional de referência. In: MÉDOLA, Ana Silvia L.D., ARAÚJO, Denise C. e BRUNO, Fernanda (orgs.). Imagem, visibilidade e cultura midiática. Porto alegre, Sulina, 2007.

BRUCK, Mozahir S. Jornalismo radiofônico e vinculação social. São Paulo: Annablume, 2003. 
COSTA, Eduardo. A Itatiaia e seus ouvintes: interação à mineira. In: PRATA, Nair (org.). O rádio entre as montanhas. Belo Horizonte, 2010.

MEDITSCH, Eduardo. A rádio na era da informação. Florianópolis: Insular, 2001. MELO, José Marque de. A opinião no jornalismo brasileiro. Petrópolis, Vozes, 1985.

SANTOS, Maria Cláudia. O local e o global. In: PRATA, Nair (org.). O rádio entre as montanhas. Belo Horizonte, 2010.

SEIXAS, Lia. Redefinindo os gêneros jornalísticos. Disponível em http://www.livroslabcom.ubi.pt/pdfs/seixas-classificacao-2009.pdf. Acesso em 02/07/2011.

TARDE, Gabriel. A opinião e a multidão. Publicações Europa-América. Mira-Sintra, 1991.

VERÓN, Eliseo. Quand lire, c'est faire. Institut de Recherces et d'Etudes Publicitaires(IREP), Paris, 1983.

Conversa de Redação. In: Jornal da Itatiaia. Rádio Itatiaia, Belo Horizonte. (Períodos analisados: 27 de setembro a 02 de outubro de 2010; 14 a 21 de fevereiro de 2011 e de 04 a 10 de julho de 2011). 


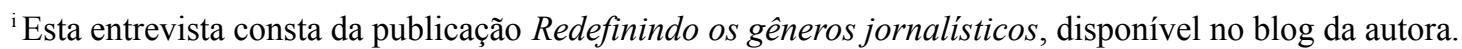

ii Gabriel Tarde escreveu A opinião e a multidão em 1901. Morreu em 1904. Conheceu mais proximamente e apenas e em seu alvorecer, a imprensa europeia - em um modelo inicialmente de jornalismo mais publicista e opinativo. Não experimentou a mídia massiva eletrônica, inaugurada pelo rádio no início do século XX.

iii Além de repórteres, Eduardo Costa e Carlos Viana também possuem programas diários próprios na emissora, no horário da tarde. Eduardo Costa apresenta o Chamada Geral, que vai ao ar das $13 \mathrm{~h}$ às $14 \mathrm{~h}$ e Carlos Viana conduz o programa Plantão da Cidade, das $16 \mathrm{~h}$ às $17 \mathrm{~h}$.

iv Agência Nacional de Telecomunicações 